\title{
PERKEMBANGAN SIKLUS HIDUP DESTINASI PARIWISATA DI INDONESIA Analisis Berdasarkan Data Makro Badan Pusat Statistik, 2002- 2012
}

\author{
Janianton Damanik, Ani Wijayanti, Awaludin Nugraha \\ 1Pusat Studi Pariwisata UGM, Kampus Bulaksumur, Blok J, No. 3, Yogyakarta;, ${ }^{3}$ Program Doktor \\ Kajian Pariwisata, Sekolah Pascasarjana UGM, Jl. Teknika Utara, Yogyakarta \\ (antondmk@yahoo.com; ani@bsi.ac.id; awaludin_nugraha@yahoo.com)
}

\begin{abstract}
ABSTRAK
Jumlah wisatawan mancanegara (wisman) dan devisa sektor pariwisata yang diraih Indonesia menunjukkan kecenderungan positif dalam 10 tahun terakhir, namun hal itu tidak menggambarkan situasi nyata perkembangan destinasi pariwisata antardaerah. Perkembangan destinasi ini diduga tidak mengikuti siklus garis linear, akibat perbedaan karakteristik setiap daerah dan faktor eksternal industri pariwisata itu sendiri. Studi ini bertujuan untuk memaparkan dinamika perkembangan destinasi pariwisata berbasis wilayah provinsi pada periode 2002-2012. Fokus analisis adalah pergeseran siklus perkembangan masing-masing destinasi dan dugaan penyebabnya. Hal ini didekati dengan mengadopsi model TALC yang banyak digunakan oleh peneliti lain. Metode deskriptif sengaja dipilih untuk memaknai data makro pariwisata yang dirilis oleh BPS. Hasil analisis menemukan: a) adanya perbedaan siklus hidup sebagian besar destinasi; b) dinamika naik-turun fase perkembangan destinasi; c) ketidaklinearan siklus hidup destinasi pariwisata; dan d) perbedaan asumsi model TALC dengan realitas perkembangan destinasi pariwisata Indonesia. Oleh karena itu, disarankan agar: a) realitas siklus hidup setiap destinasi diadopsi sebagai basis perumusan kebijakan pengembangan destinasi secara lebih tepat; dan $b$ ) kajian lebih lanjut dilakukan dengan cara menambah parameter perkembangan destinasi.
\end{abstract}

Kata Kunci:

perkembangan, siklus-hidup, destinasi, pariwisata, provinsi.

\begin{abstract}
The number of international tourists and foreign exchange received by Indonesia shows a positive trend in the late 10 years, but it does not portray enough the real growth of intra-regional tourism destinations. It can be supposed that this growth did not follow a linear life cycle of destination due to the specific
\end{abstract}


characteristics of each region and the external factors of tourism industry itself. This study intends to explain the dynamics of growth of tourism destinations based on province area in the period of 2002-2012. The analysis focuses on the shift of the destination development and its causes. It will approached by the adoption of TALC model which has been already used by the researchers before. The descriptive methods was used to interpret the macro data published by BPS. The study finds out: a) a difference of the life cycle of the most tourism destinations; $b$ ) a dynamics of up-and-down destination development; c) the unlinearity of the life cycle of tourism destination; d) the assumption difference of TALC model with the fact of the destination development phase in Indonesia. Therefore it is suggested, that: a) the real life cycle of tourism destination should be adopted as a basis for policy-making in destination development; b) a further study should be run by adding a comprehensive parameters of the destination development.

Key words:

development, life-cycle, destination, tourism, province.

\section{PENDAHULUAN}

Indonesia mencatatkan diri sebagai salah satu destinasi pariwisata yang penting di kawasan Asia. Hal ini terjadi akibat kinerja sektor pariwisata terus meningkat dalam 10 tahun terakhir. Jumlah wisatawan mancanegara (wisman) tercatat sebanyak 5,033 juta (2002) dan naik menjadi 8,044 juta orang (2012). Tren ini diikuti oleh jumlah devisa yang diraih naik dari 4,305 milyar US\$ (2002) menjadi 9,120 milyar US\$ (2012) (www.bps.go.id). Selain itu jumlah wisatawan nusantara (wisnus) juga naik secara signifikan dari 225,0 juta (2008) menjadi 245,3 juta (2012) dengan total pengeluaran bergerak dari Rp 123 triliun ke angka Rp 171 triliun (Pusdatin Kemenparekraf, t.t.).

Secara nasional angka ini menunjukkan sinyal perkembangan positif dan menjanjikan. Efeknya juga signifikan terhadap penyerapan tenaga kerja, sebab diasumsikan sektor pariwisata memiliki efek pengganda yang besar (WTO, 2007; Booth, 1990). Namun catatan kritis perlu diberikan. Distribusi perkembangan pariwisata tidak merata di tingkat provinsi, apalagi di tingkat kawasan pariwisata. Secara geografis konsentrasi wisatawan tetap berada di Pulau Jawa dan Pulau Bali. Penyebabnya terkait dengan sejarah kolonial yang menjadikan kedua pulau strategis tersebut sebagai sentra pertumbuhan ekonomi negara jajahan (Lombard, 2005; Picard, 2006). Hingga kini ketimpangan itu masih terasa, meskipun di beberapa daerah, seperti Sumatera Utara,
Kepulauan Riau, dan Sulawesi Selatan, terjadi perkembangan yang signifikan.

Faktor lain yang diduga menimbulkan kesenjangan tersebut adalah interkoneksi yang lemah antara $h u b$ dengan beberapa provinsi di luar Pulau Jawa maupun Bali. Akibatnya, kedatangan wisatawan, terutama mancanegara, tidak mudah tersebar ke berbagai daerah. Hal ini diperburuk oleh manajemen destinasi yang lemah dan kurang responsif terhadap perubahan kebutuhan pasar wisatawan. Kebijakan pemerintah yang sering kontraproduktif, misalnya inkonsistensi dukungan politik dan finansial pada pengembangan dan pemasaran destinasi, ikut menghambat perkembangan destinasi tersebut.

Sejauh ini belum ada kajian terbaru tentang siklus perkembangan kawasan pariwisata dengan basis provinsi. Studi yang dilakukan Putra \& Hitchcock (2006) tentang efek terorisme terhadap siklus hidup pariwisata provinsi Bali tampaknya menarik, meskipun lebih fokus pada satu kawasan sehingga tidak dapat dibandingkan dengan kawasan lainnya. Artinya, perubahan yang terjadi dalam garis perkembangan destinasi pariwisata Bali hanya bersifat lokal dan temporer. Sekitar satu dasawarsa sebelumnya peneliti lain menganalisis siklus perkembangan destinasi pariwisata Indonesia berbasis provinsi (Sofield, 1995). Diperoleh simpulan, bahwa hanya provinsi Bali yang mencatat tingkat perkembangan tertinggi. 
Artikel ini berangkat dari suatu asumsi, bahwa siklus hidup destinasi pariwisata di tingkat provinsi mengalami pasang surut dalam 5-10 tahun terakhir. Oleh sebab itu dinamika yang terjadi dalam siklus tersebut perlu dikaji secara lebih kritis. Pertanyaan pokok yang ingin dijawab adalah bagaimana dinamika siklus hidup destinasi pariwisata (baca: provinsi) di Indonesia dalam 10 tahun terakhir? Siklus destinasi pariwisata mana yang relatif stabil dan mengapa demikian? Sejalan dengan hal itu, tujuan artikel ini dibatasi pada: a) pemetaan fase perkembangan destinasi pariwisata berbasis provinsi di Indonesia dengan menggunakan pendekatan model siklus hidup kawasan pariwisata (tourism area life cycle - TALC) serta menguji keabsahan pendekatan tersebut; b) deskripsi pergeseran siklus hidup destinasi berdasarkan satuan waktu tertentu.

\section{TINJAUAN PUSTAKA}

Masalah yang diajukan di atas didekati dengan menggunakan model umum TALC yang dikenalkan pertama sekali oleh Butler (1980; 2006a). Menurutnya, terdapat kesamaan antara siklus hidup destinasi dengan siklus hidup produk barang dan jasa: mula-mula berjalan lambat, kemudian tumbuh lebih cepat, terus stabil, hingga akhirnya menurun mengikuti alur atau kurva dasar asimtosis. Disebutkan, bahwa siklus hidup kawasan pariwisata terdiri dari 6 fase, yakni: penemuan (exploration), keterlibatan (involvement), perkembangan (development), konsolidasi (consolidation), stagnasi (stagnation) dan kemungkinan fase peremajaan (rejunevation) atau penurunan (decline) (Butler, 1980). Fase eksplorasi ditandai oleh kunjungan wisatawan avonturir atau bertipe alosentris (Plog, 2001) dan beberapa pelaku pariwisata. Jumlah wisatawan masih terbatas. Infrastruktur dan fasilitas kawasan ini belum memadai, karena masih baru ditemukan; bahkan sebagian di antaranya bahkan merupakan fasilitas yang digunakan oleh penduduk setempat. Hubungan wisatawan dengan penduduk cukup kuat dan masalah lingkungan dan sosial yang muncul relatif belum menonjol.

Tahap keterlibatan ditandai oleh terjadinya kontak yang semakin intensif antara wisatawan dengan masyarakat lokal. Hal ini terjadi akibat kunjungan wisatawan semakin meningkat. Warga masyarakat mulai menyediakan berbagai fasilitas yang secara khusus diperuntukkan bagi wisatawan. Baik kegiatan promosi maupun pembentukan unit-unit bisnis pariwisata diprakarsai dan dikembangkan oleh masyarakat. Kontak sosial antara masyarakat dengan wisatawan ditandai oleh pertukaran ekonomi yang rasional. Kebutuhan infrastruktur yang semakin meningkat menyebabkan pemerintah, di samping penduduk lokal, terlibat "to provide or improve transport and others facilities for visitors" (Butler, 1980: 8). Dukungan dan kepentingan pemerintah untuk memajukan destinasi menjadi semakin kuat.

Selanjutnya, fase perkembangan ditandai oleh "a well-defined tourist market area, shaped in part by heavy advertising in tourist-generating areas" (Butler, 1980: 8). Pasar wisatawan relatif terpola dan cenderung berifat massal (mass tourism). Pada musim puncak kunjungan, jumlah wisatawan bahkan sering melebihi jumlah penduduk lokal. Keragaman atraksi, pola pengelolaan kawasan, dan jenis kelembagaan berkembang pesat berkat volume investasi dari luar yang terus meningkat. Misalnya, penggunaan atraksi berbasis alam dan budaya sangat intensif dan berimplikasi pada perubahan fisik kawasan. Hal ini diikuti oleh pengembangan atraksi buatan yang komponenkomponen fisik dan manajemennya berasal dari luar daerah atau luar negeri. Kegiatan promosi dilakukan secara lebih intensif; demikian pula mutu fasilitas kawasan semakin baik dan mengikuti standar internasional. Perubahan tampilan fisik kawasan akibat desakan pengembangan atraksi cukup menonjol dan biasanya tidak diinginkan oleh komunitas setempat. 


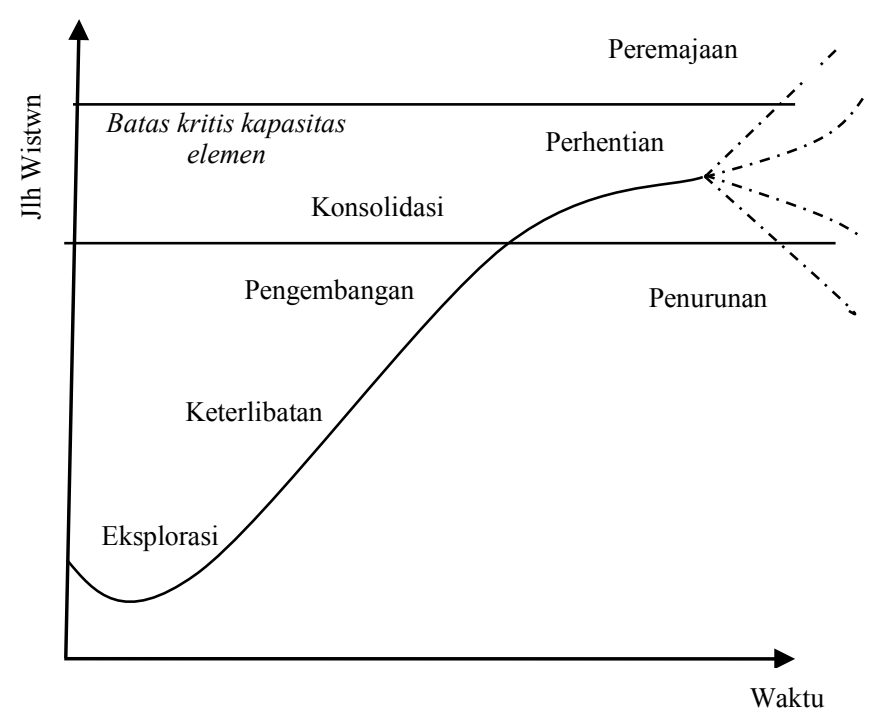

Gambar 1.

Model Siklus Hidup Kawasan Pariwisata (Sumber: Butler, 1980)

Pada tahap konsolidasi tingkat pertumbuhan wisatawan ke kawasan mulai menurun, meskipun secara absolut angkanya naik. Hal yang menonjol adalah bahwa sebagian besar aktivitas ekonomi masyarakat didominasi oleh atau berkaitan dengan pariwisata. Unit-unit bisnis, bentuk kelembagaan, usaha berlisensi asing, model kemitraan lintas-pelaku, dan regulasi pemerintah menjadi acuan di dalam kegiatan bisnis. Kolaborasi lintas institusi tumbuh berbasis kepentingan yang sama dan formatnya semakin kompleks (Haywood, 2006), yang oleh Butler disebut sebagai institutionalism. Selain itu, jumlah pengunjung yang besar dan pengembangan fasilitas yang lebih berorientasi pada kebutuhan wisatawan mengakibatkan kepentingan penduduk lokal sering terabaikan. Konsekuensi yang logis adalah munculnya sikap penolakan dan antagonisme masyarakat terhadap pariwisata. Mereka cenderung antipati karena pariwisata dipandang membatasi ruang dan akses mereka pada fasilitas umum yang sebenarnya juga menjadi haknya (Johnston \& Snepenger, 2005). Reaksi negatif ini dapat dipahami sebagai salah satu bentuk dampak sosial, ekonomi dan budaya perkembangan pariwisata (Marois \& Hinch, 2006) yang sangat krusial di dalam pengelolaan destinasi pariwisata.

Pada fase stagnasi, perkembangan pariwisata masih relatif sama dengan sebelumnya. Namun demikian, jumlah wisatawan dan kemampuan industri pariwisata sudah maksimal. Hingga taraf tertentu, daya dukung fisik (carrying capacity) kawasan tampak berlebih, sehingga berdampak negatif terhadap lingkungan, sosial dan ekonomi. Misalnya, kesan positif sebagai kawasan pariwisata mulai memudar, meskipun volume pengunjung-balik (repeater) masih bertahan. Pada umumnya tampilan kawasan pariwisata lebih bersifat artifisial. Inilah yang menjadi salah satu alasan untuk melakukan pengembangan fisik ke luar kawasan. Ditekankan oleh Butler, bahwa tipe wisatawan yang berkunjung pada tahap ini adalah wisatawan terorganisir dan massal, seperti diidentifikasi oleh Cohen (1979), atau wisatawan bertipe psikosentris seperti yang digambarkan oleh Plog (2001).

Setelah mencapai fase stagnasi, kawasan pariwisata menghadapi dua kemungkinan, yakni penurunan (decline) atau peremajaan kembali (rejuvenation). Karakteristik penurunan ini antara lain: wisatawan biasanya meninggalkan kawasan kecuali untuk berakhir pekan, dan alih kepemilikan usaha pariwisata terjadi secara intensif. Sejumlah fasilitas pariwisata beralihfungsi menjadi fasilitas umum non-pariwisata dan penduduk lokal berpeluang untuk membeli kembali properti itu dengan harga lebih murah. Akibatnya, kawasan semakin tidak menarik bagi wisatawan. Pada kasus yang ekstrem, kawasan tersebut bisa berubah menjadi daerah slum dan kehilangan fungsi aslinya. Kemungkinan kedua adalah peremajaan kembali secara inovatif, antara lain: mengubah pemanfaatan kawasan, mencari pasar wisatawan baru, membuat kanal pemasaran baru atau mereposisi atraksi wisata ke bentuk lain.

Seperti ditulis oleh Butler, TALC digunakan untuk menggambarkan dan memahami "the 
process of the development of tourists destinations in a wide variety of settings" (Butler, 2011: 3). Ia tidak hanya digunakan untuk memotret lokus mikro, seperti museum sebagai unit atraksi di kota, tetapi juga ruang kawasan yang lebih luas, seperti kawasan strategis pariwisata, kabupaten atau bahkan provinsi (Butler, 2006b). Para peneliti telah lama menggunakan model ini sebagai kerangka analisis dengan skala kawasan kecil dan tunggal, seperti Niagara Falls (Getz, 1992), resort wisata (Andriotis, 2010) atau kawasan industri pariwisata (Kamat, 2010), maupun di taman nasional (Bo \& Zhang, 2006; Boyd, 2006; Johnston \& Snepenger, 2006). Di Indonesia kajian tentang penerapan TALC pertama kali dilakukan oleh Sofield (1995) yang memotret tendensi siklus hidup pariwisata di berbagai provinsi di Indonesia, namun basis analisisnya terbatas hanya pada indikator jumlah wisatawan. Model TALC juga dijadikan sebagai landasan analisis terhadap kawasan pariwisata Danau Toba dan menunjukkan diferensiasi tahap perkembangan berdasarkan sejumlah indikator atraksi dan pasar wisatawan (Lumbanraja, 2012).

Salah satu kritik terhadap model TALC adalah asumsi bahwa perkembangan kawasan pariwisata, apakah di level mikro, meso atau makro, terjadi secara linear. Dalam kasus Bali, misalnya, Putra \& Hitchcock (2006) menemukan hal yang berbeda. Salah satu fakta adalah bahwa gejolak politik kekerasan (Bom Bali) secara beruntun membuat perkembangan pariwisata Bali tidak mencapai fase konsolidasi. Kritik kedua adalah indikator siklus hidup kawasan yang digunakan dalam model TALC adalah jumlah wisatawan, meskipun Butler mengakui pengaruh kehadiran entitas bisnis atau perubahan fisik kawasan. Oleh sebab itu, parameter tambahan dapat dipakai untuk melengkapi indikator tersebut. Strapp (dikutip Putra \& Hitchcock, 2006), misalnya, menggunakan ukuran rerata lama tinggal untuk mengakomodasi perubahan status wisatawan yang cenderung menetap dalam jangka panjang di destinasi. Cooper (2002) mengajukan beberapa indikator, seperti: tingkat pertumbuhan wisatawan, rasio repeaters dengan first timers, lama tinggal, profil wisatawan, pengeluaran per kapita, dan pengaturan perjalanan sebagai bagian yang tidak terpisahkan dalam pertumbuhan destinasi.

Jelas, bahwa siklus hidup destinasi sangat terkait pada faktor internal dan eksternal. Deskripsi yang dibuat oleh Butler condong menyoroti faktor internal. Faktor eksternal yang sangat berpengaruh adalah iklim politik nasional dan global. Perang, wabah penyakit, konflik dan terorisme berdampak serius pada perkembangan destinasi (Pulina \& Biagi, 2006; Asia-Pacific Economic Cooperation, 2004; Hitchcock \& Putra, 2007; Damanik, 2009). Faktor eksternal ini dapat mengakibatkan destinasi yang baru pada fase pengembangan tidak bergerak ke tahap berikutnya. Seperti disinggung Putra \& Hitchcock (2006), kasus Bali menggambarkan efek faktor eksternal terhadap siklus hidup destinasi.

Paparan di atas menjadi basis konseptual yang digunakan untuk menguji secara kritis dinamika internal maupun eksternal destinasi pariwisata. Dalam artikel ini hal yang sama juga digunakan untuk memetakan siklus hidup setiap destinasi dengan menempatkan provinsi sebagai satuan kawasan pariwisata.

\section{METODE PENELITIAN}

Data yang dijadikan bahan analisis adalah data makro yang dipublikasi oleh Badan Pusat Statistik (www.bps.go.id). Data ini terdiri dari jumlah wisatawan mancanegara dan nusantara, jumlah hotel bintang dan non bintang, dan ratarata lama tinggal wisatawan di setiap provinsi dalam satu tahun. Ketiga data ini lebih lengkap dibandingkan dengan data asumtif yang digunakan oleh Butler dalam analisis tentang TALC.

Berikut ini akan diuraikan cara kajian. Pertama, data jumlah hotel (jh), dan lama 
tinggal (length of stay - LoS) di setiap provinsi pada tahun 2002 dan 2012 diolah dengan cara menggabungkan masing-masing ke dalam 6 kelompok. Adapun jumlah wisatawan (jw) di setiap provinsi dihitung dari data tahun 2003 dan 2012, karena data tahun 2002 tidak tersedia dengan karakteristik yang sama dengan tahun sesudahnya. Enam kelompok ini adalah representasi dari tahapan siklus hidup destinasi. Interval kelompok (i) ditentukan dengan menghitung jumlah wisatawan terbanyak (jwb) dikurangi jumlah wisatawan paling sedikit (jws) dibagi 6 atau $\{(j w b)-$ $(j w s) / 6)\}$. Kelompok pertama adalah $\{(j w s)$ sampai $(j w s)+(i)\}$. Demikian seterusnya hingga 6 kelompok terbentuk, masing-masing bernilai $1,2,3,4,5,6$. Prosedur ini juga berlaku untuk menentukan interval (i) pada $j h$, yakni dengan cara menghitung jumlah hotel terbanyak $(j h b)$ dan jumlah hotel paling sedikit ( $j h s)$. Selanjutnya (jhb) dikurangi (jhs) dibagi 6 atau $\{(j h b)-(j h s) / 6)\}$. Dengan demikian, kelompok pertama adalah $\{(j h s)$ sampai $(j h s)+(i)\}$. Demikian seterusnya hingga 6 kelompok terbentuk, masing-masing bernilai 1, 2, 3, 4, 5, 6. Cara menghitung 6 kelompok variabel lama tinggal ( $L O S)$ juga sama. Intervalnya ditentukan dari hasil rerata LoS tertinggi (lt) dikurang LoS terendah (lr) dibagi 6 atau $\{(l t)-(l r) / 6)\}$. Kelompok LoS pertama adalah $\{(l r)$ sampai $(l r)+(i)\}$. Demikian seterusnya hingga 6 kelompok terbentuk, masing-masing bernilai 1, 2, 3, 4, 5, 6 .

Kedua, pembobotan kelompok variabel jumlah wisatawan (jw) sebesar 40 persen, variabel jumlah hotel ( $j h$ ) dan LoS masingmasing 30 persen. Bobot yang lebih besar pada variabel (jw) didasarkan pada expert judgement saja dan asumsi, bahwa jumlah wisatawan merupakan indikator utama siklus hidup kawasan (Butler, 2006b). Selanjutnya, masingmasing nilai kelompok variabel dikali bobot variabel. Perhitungan skor variabel jumlah wisatawan adalah sbb: $1 \times 40 ; 2 \times 40 ; . . . ; 6 \times 40$, sementara skor variabel jumlah hotel dan LoS adalah $1 \times 30 ; 2 \times 30 ; . . . ; 6 \times 30$.
Ketiga, penggabungan hasil perhitungan skor total variabel $(S t v)=(j w+j h+L o S)$ masingmasing provinsi tahun 2003 dan 2012 untuk jumlah wisatawan dan 2002-2012 untuk jumlah hotel dan LoS. Hasilnya dikelompokkan ke dalam 6 kelas. Intervalnya (i) ditentukan dengan cara menghitung skor total variabel tertinggi (Stv.t) dikurang skor total variabel terendah (Stv.r) dibagi 6 atau $\{($ Stv.t $)-($ Stv.r) $/ 6)\}$. Jadi, kelompok pertama (1) adalah \{(Stv.r) - (Stv.r)+ (i)\}. Kelompok 2, 3, 4, 5, dan 6 dihitung dengan cara yang sama. Provinsi yang meraih nilai kelompok 1 dimasukkan ke kelas destinasi pada fase penemuan, provinsi yang meraih nilai kelompok 2 masuk ke fase keterlibatan, provinsi yang meraih nilai kelompok 3 masuk ke fase perkembangan, provinsi yang meraih nilai kelompok 4 masuk ke fase konsolidasi, provinsi yang meraih nilai kelompok 5 masuk ke fase stagnasi, provinsi yang meraih nilai kelompok 6 masuk ke peremajaan atau penurunan.

\section{HASIL DAN PEMBAHASAN}

Perkembangan destinasi pariwisata Indonesia berdasarkan provinsi berbeda secara signifikan. Perbedaan tersebut sebagian terjadi akibat pemekaran wilayah provinsi (Banten, Gorontalo, Sulawesi Barat, Papua Barat, Bangka Belitung, Kepulauan Riau, Maluku Utara) yang secara otomatis mengurangi angka wisatawan di provinsi induk pada tahun 2012. Dengan mengecualikan faktor tersebut, studi ini menemukan fakta yang cukup menarik dalam konteks TALC, antara lain variasi fase perkembangan siklus hidup destinasi.

\section{Fase Eksplorasi yang Stagnan}

Jangka waktu 10 tahun terbukti belum cukup untuk mengubah siklus hidup sejumlah destinasi pariwisata di Indonesia. Provinsi Sumbar, Jambi, Lampung, Kalbar, Kalteng, Kaltim, dan Papua yang pada tahun 2002 berada pada fase eksplorasi, tercatat mengalami 
fase eksplorasi yang stagnan, karena sepuluh tahun kemudian semuanya masih tetap pada posisi yang sama. Salah satu faktor yang diduga menjadi penyebabnya adalah variasi daya tarik. Perkembangan unit-unit atau keragaman daya tarik pariwisata di provinsi tersebut secara kuantitatif relatif lambat. Di Sumbar memang sudah ada atraksi pariwisata bertaraf internasional, Tour de Singkarak, tetapi efeknya untuk menarik jumlah wisatawan belum cukup kuat. Event festival tingkat lokalnasional, seperti: Festival Krakatau (Lampung) sejak tahun 1990-an, Festival Candi Muara Jambi (Jambi), Festival Seni Budaya Melayu (Kalbar), Festival Seni Budaya Dayak (Kalteng), Festival Erau (Kaltim), Festival Danau Sentani (Papua) tampaknya belum efektif menarik pasar internasional, sehingga kurang berdampak pada pertumbuhan akomodasi dan lama tinggal wisatawan.

Fakta yang juga menarik adalah siklus hidup Provinsi Sumsel dan Maluku yang bergerak dari fase eksplorasi ke fase keterlibatan. Kedua provinsi ini sebenarnya tidak tergolong destinasi yang populer bagi wisatawan atau menawarkan begitu banyak aktraksi. Namun demikian, perhelatan nasional dan internasional (PON dan SEA Games) maupun MTQN Maluku diduga ikut memberikan kontribusi yang signifikan bagi perkembangan destinasi tersebut.

\section{Dinamika Fase Keterlibatan}

Siklus dinamis terjadi pada fase keterlibatan. Ada tiga pola dinamika pada fase ini. Pertama, sejumlah destinasi (Aceh, Bengkulu, NTT, Sultra, Sulteng, dan Sulut) mengalami kemunduran (set back) dari fase keterlibatan (2002) menuju fase eksplorasi (2012) (lihat Gambar 2 dan 3). Agaknya sulit dibantah, bahwa provinsi tersebut, mungkin sedikit perkecualian dengan Provinsi Sulut, kurang ekspansif di dalam pengembangan infrastruktur dan promosi destinasinya baik di dalam maupun ke luar negeri. Sedikit mengejutkan, siklus hidup destinasi Sulut mengalami kemunduran dalam 10 tahun terakhir. Sulit menjelaskan mengapa kemunduran ini terjadi. Pemekaran Provinsi Gorontalo tampaknya bukanlah alasan yang tepat, sebab perkembangan pariwisata di provinsi ini pun termasuk tidak signifikan. Padahal, Provinsi Sulut telah lama dikenal sebagai salah satu destinasi penting berkat daya tarik alam dan budayanya. Pagelaran Sail Bunaken dan Tomohon International Flower Festival secara rutin, tampaknya belum mampu mendongkrak kunjungan wisatawan internasional maupun antar-pulau dalam negeri. Hampir sama halnya dengan Provinsi Bengkulu. Harus diakui, secara faktual daerah ini belum menduduki tempat strategis di dalam peta pariwisata nasional. Terlepas dari adanya pantai yang potensial sebagai atraksi, dukungan politik nasional untuk mengembangkan destinasi ini belum signifikan.

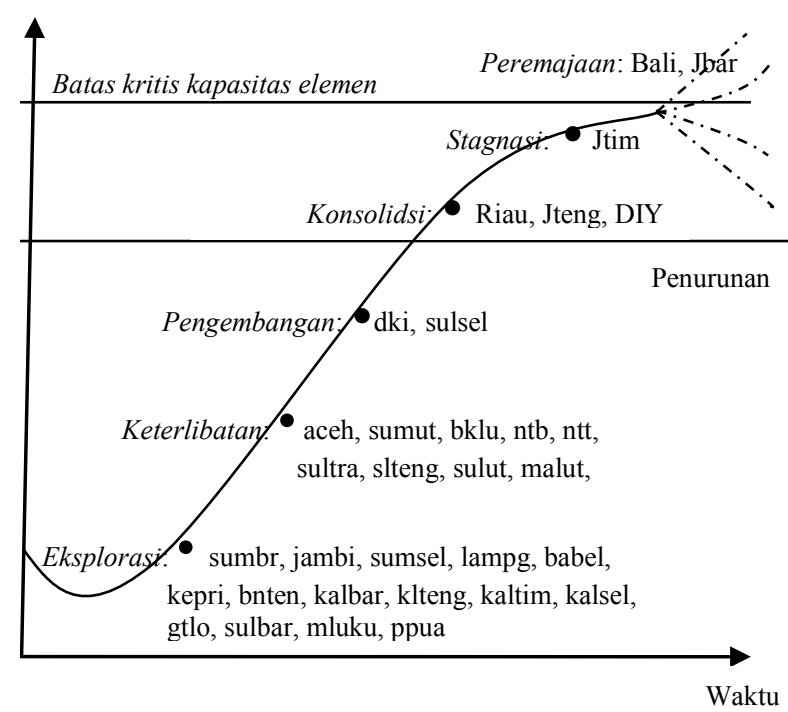

Gambar 2.

Siklus Hidup Destinasi Pariwisata Tahun 2002

Provinsi Aceh dan Sulteng menghadapi masalah kesan negatif dari dunia internasional akibat isu kerawanan keamanan, sehingga dukungan bagi pembangunan pariwisata tidak maksimal. Secara umum pengembangan pariwisata tidak menjadi skala prioritas bagi 
kedua daerah. Efek panjang tsunami tahun 2004 juga diduga cukup kuat terhadap kemunduran perkembangan pariwisata di Aceh. Provinsi NTT sebenarnya memiliki peluang besar mengikuti siklus lanjutan secara positif berkat promosi destinasi ekowisata melalui event Sail Komodo. Namun demikian, aksesibilitas yang masih terbatas menjadi kendala untuk bergerak positif ke fase yang lebih tinggi. Di samping itu, atraksi pariwisata berbasis alam yang menjadi andalan provinsi ini mengakibatkan pasar wisatawan juga tersegmentasi pada kelompok ekowisatawan (Walpole \& Goodwin, 2000). Salah satu karakteristik ekowisatawan adalah berkelompok kecil (Hoskins, 2002). Akibatnya jumlah wisatawan menjadi relatif kecil. Kondisi infrastruktur transportasi darat maupun laut yang kurang mendukung sangat berperan dalam kemunduran siklus hidup destinasi yang strategis ini.

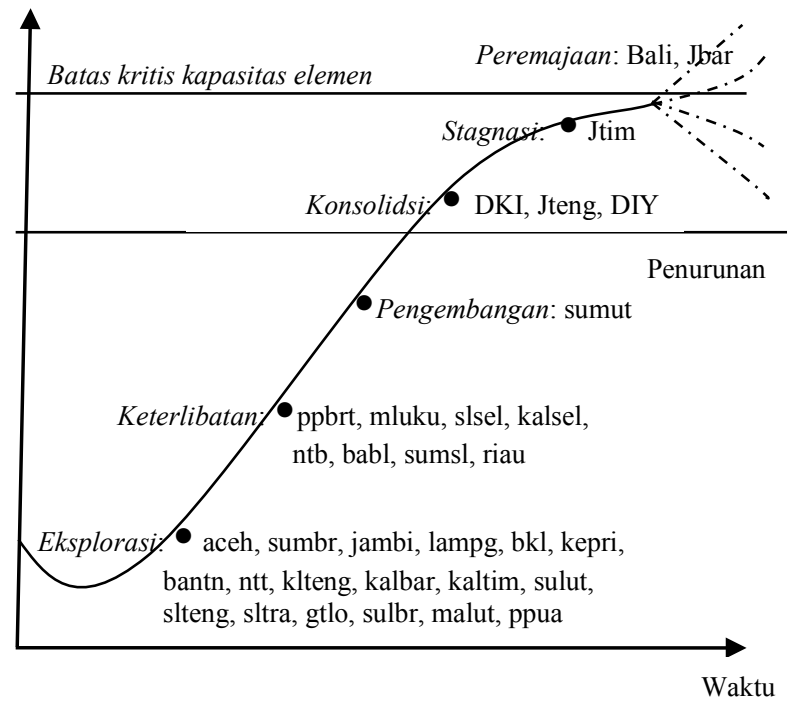

Gambar 3.

Siklus Hidup Destinasi Pariwisata Tahun 2012

Kedua, tahun 2012 provinsi NTB bertahan pada posisi yang sama seperti tahun 2002. Sebenarnya pertambahan infrastruktur hotel tercatat memadai, didukung oleh pembukaan bandara internasional, namun pertambahan jumlah wisatawan tidak sepesat daerah lain, misalnya Bali. Faktor lain yang diduga berperan di balik fakta ini adalah perkembangan kawasan pariwisata yang terkonsentrasi di Pulau Lombok, khususnya kawasan Pantai Senggigi, Gili Air, Gili Meno, dan Gili Trawangan. Hampir sama dengan NTT, khususnya Pulau Flores, segmen wisatawan yang berkunjung ke kawasan ini adalah kalangan minat khusus, sehingga secara kuantitatif jumlahnya terbatas. Perkembangan fisik kawasan sentra pariwisata di pulau-pulau kecil tampaknya sudah mulai jenuh, sehingga orientasi pengembangan dimulai ke arah selatan pulau "sejuta masjid" itu.

Ketiga, di pihak lain, Provinsi Sumut bergerak positif dari fase keterlibatan (2002) ke fase pengembangan (2012). Artinya, gerak siklikal yang dicapai provinsi dengan pertumbuhan ekonomi yang pesat ini berkaitan dengan statusnya sebagai pintu gerbang wisatawan internasional, khususnya dari negara jiran. Seperti ditulis oleh Butler (1980; 2006a) fase keterlibatan ditandai oleh peningkatan perbaikan infrastruktur. Hal yang sama terjadi di sejumlah provinsi (Aceh pasca-tsunami). Di Provinsi NTB, khususnya Pulau Lombok, dibangun Bandara Internasional Lombok di lokasi yang berbeda dengan bandara lama dan menelan biaya hampir 1 triliun rupiah. Di kawasan Pantai Kuta, Lombok bagian Selatan, resort dengan investasi oleh jaringan hotel internasional juga dibangun sejak pertengahan tahun 2000-an. Menyangkut siklus hidup positif destinasi Provinsi Kalsel tampaknya berkaitan dengan peningkatan jumlah wisatawan, khususnya wisman, ke kawasan konservasi Tanjung Puting. Atraksi ekowisata ini telah lama menjadi semacam "ikon" bagi pecinta lingkungan dan mendapat perhatian dunia internasional.

\section{Fase Pengembangan yang Dikotomis}

Pada fase pengembangan terjadi siklus yang berbeda pada dua destinasi. Tahun 2002 Provinsi DKI dan Sulsel berada pada 
fase siklus ini. Namun 10 tahun kemudian DKI bergerak maju ke fase berikutnya, yakni konsolidasi, sedangkan Sulsel bergerak mundur ke fase keterlibatan. Mengapa demikian? Pertumbuhan infrastruktur pariwisata yang pesat, variasi dan intensitas event yang tinggi, dan posisi Jakarta sebagai Ibukota Negara yang menjadi hub sekaligus pintu gerbang keluar-masuk wisatawan internasional dapat dipandang sebagai alasan mengapa gerak siklus hidup destinasi ini mengarah secara positif-vertikal. Meskipun demikian, siklusnya yang bergerak dari fase pengembangan ke konsolidasi sebenarnya termasuk "lambat", mengingat ibukota ini nyaris tidak pernah sepi dari beragam event budaya, ekonomi dan politik sepanjang tahun. Kita dapat menduga, bahwa perkembangan infrastruktur pariwisata bergeser dari pusat pertumbuhan ekonomi nasional tersebut ke daerah periferinya, yakni Bogor, Depok, Tangerang, dan Bekasi.

Sebaliknya, Provinsi Sulsel menghadapi efek pemekaran provinsi dengan lahirnya Sulawesi Barat, sehingga "memecah" baik distribusi hotel maupun jumlah wisatawan pada tahun 2012. Pintu masuk wisatawan internasional ke Tana Toraja tidak sepenuhnya melalui Makassar, tetapi langsung menuju ibukota provinsi baru itu. Faktor lain diduga berkaitan dengan pola pengembangan pariwisata yang terkonsentrasi di sekitar Kota Makassar yang sebenarnya juga mulai mengalami kejenuhan. Kedua provinsi ini meninggalkan fase pengembangan dengan arah yang berbeda dan berpola dikotomis, sekaligus menunjukkan bahwa tren perkembangan destinasi pariwisata secara nasional tidak mengalami banyak kemajuan.

\section{Fase Konsolidasi secara Involutif?}

Dalam 10 tahun terakhir tampak bahwa tidak satu pun provinsi yang mencatat siklus hidup positif-vertikal. Gambar 2 dan 3 di atas secara eksplisit menggambarkan hal ini. Jateng dan DIY yang pada tahun 2002 sudah berada pada fase konsolidasi ternyata tidak bergeser ke tingkat perkembangan berikutnya (stagnasi) pada tahun 2012. Apakah hal ini menggambarkan suatu perkembangan yang bersifat involutif, yakni perkembangan yang ditandai oleh dinamika pertumbuhan yang statis, baik dalam jumlah wisatawan, jumlah atraksi, jumlah akomodasi dan lama tinggal? Jawabnya, boleh jadi demikian jika kita menimbang faktor LoS secara umum. Provinsi DIY, misalnya, mencatat pertambahan jumlah wisatawan nusantara yang sangat berarti, tetapi sebaliknya pertambahan jumlah wisatawan mancanegara masih jauh tertinggal. Pembangunan infrastruktur hotel terus terjadi dan bahkan pembangunan bandara bertaraf internasional sudah direncanakan sejak 5 tahun silam. Selain itu, rerata LoS wisatawan tergolong pendek, masih pada kisaran 2 malam. Situasi ini sudah berjalan cukup lama, sekalipun berbagai upaya promosi giat dilakukan. Diskursus yang terus berkembang mencuatkan faktor "destinasi kedua setelah DKI atau Bali" sebagai penyebab rendahnya LoS di DIY. Artinya, wisman memilih destinasi ini bukan sebagai destinasi utama, melainkan kedua atau bahkan ketiga setelah Bali. Wilayahnya yang tidak luas dan berkat infrastruktur transportasi yang terandalkan membuat atraksi pariwisata yang tersedia dapat dijangkau dengan mudah, cepat, dan murah. Hal ini juga mengakibatkan wisatawan pada umumnya tidak membutuhkan waktu yang lama di destinasi berlabel istimewa ini.

Karakter involutif juga terlacak pada Provinsi Jateng. Segmen pasar wisatawan di sini adalah wisatawan nusantara yang melakukan pergerakan yang cukup intensif dari satu destinasi ke destinasi lain dan relatif terbatas pada waktu yang pendek (Damanik \& Cemporaningsih, 2012). Secara kuantitatif terjadi pertambahan jumlah hotel dari tahun ke tahun di berbagai kota, khususnya Solo, Magelang, dan Purwokerto, dan berbagai atraksi budaya terus dipromosikan di berbagai kota. Namun demikian perlu dicatat, bahwa secara umum simptom antagonism masyarakat, 
seperti diasumsikan oleh Butler, belum mencuat pada fase ini.

Cukup menarik untuk dicatat, bahwa Provinsi Riau tidak menjadi bagian dari konsolidasi involutif di atas. Sebaliknya ia mengalami siklus vertikal-negatif dari fase konsolidasi pada tahun 2002 menjadi fase keterlibatan tahun 2012 (lihat Gambar 2 \& 3). Derajat kemunduran ini sangat menukik karena melangkahi satu tingkat, yakni fase pengembangan. Inilah satu-satunya destinasi yang mengalami siklus mundur yang ekstrem. Penyebab yang paling mungkin adalah faktor pemekaran (Provinsi Kepulauan Riau). Kawasan pariwisata utama yang dulu menyatu dalam satu provinsi, kini terintegrasi di bawah provinsi baru tersebut. Pulau Batam dan Pulau Bintan merupakan sentra pertumbuhan ekonomi pariwisata yang pesat bukan lagi menjadi bagian Provinsi Riau kini. Riau daratan sendiri relatif tidak memiliki banyak sumberdaya pariwisata, sehingga perkembangan pariwisatanya kembali ke titik nol pasca pemekaran provinsi tersebut.

\section{Stagnasi Lemah}

Siklus hidup destinasi pariwisata pada fase stagnasi sangat lemah atau lambat. Hal ini terlihat dari ketiadaan destinasi pariwisata provinsi yang mengalami pergeseran vertikalpositif (maju) maupun vertikal negatif (mundur). Provinsi Jawa Timur (Jatim) merupakan satu-satunya destinasi yang berada pada fase stagnasi pada tahun 2002. Artinya, dibanding dengan provinsi lainnya, selain Bali dan Jabar, pada waktu itu perkembangan pariwisata Jatim tergolong tinggi. Kondisi yang sama terus bertahan sampai tahun 2012. Dalam 10 tahun tersebut pariwisata Jatim bergerak lambat, tidak mundur tetapi juga tidak mencatat perubahan drastis. Kita dapat memaknai hal ini dengan melihat keberadaan kawasan pariwisata yang cukup mapan (Batu/Malang, TN Baluran, TN Meru Betiri, TN Blambangan, Pasir Putih, dan lainnya). Sejumlah kota juga menggelar event secara rutin, seperti Festival Banyuwangi,
Festival Karnaval Jember, selain berbagai event budaya dan pariwisata di Kota Surabaya sendiri. Format pariwisata massal yang menjadi ciri fase ini diwakili oleh keberadaan Jatim Park yang menyedot banyak wisatawan nusantara. Event berskala regional (ASEAN Tourism Forum) yang digelar tahun 2012, dapat dipandang sebagai bagian dari upaya mempertahankan status perkembangan pariwisata setempat. Singkatnya, keberadaan hanya satu destinasi pada siklus stagnasi selama 10 tahun menunjukkan tingkat perkembangan destinasi pariwisata Indonesia secara umum tergolong lemah.

\section{Peremajaan yang Mapan}

Fase peremajaan yang mapan dilekatkan pada Provinsi Bali dan Jabar, karena posisi siklus hidup destinasi itu tidak mengalami kemunduran dalam jangka waktu 10 tahun. Pariwisata Bali memang sempat terguncang hebat pasca Bom Bali (Putra \& Hitchcock, 2006), namun turbulensi itu hanya berdurasi relatif pendek. Promosi secara gencar melalui sejumlah MICE berskala internasional, antara lain PATA Congress (2003) dan World Geothermal Congress (2010), ikut mempercepat pemulihan tersebut. Karakteristik yang menonjol pada destinasi mapan ini adalah berkembangnya infrastruktur akomodasi bertipe vila yang dimiliki investor luar dan jumlah wisatawan yang terus bertambah. Data menunjukkan, bahwa dominasi Bali sebagai destinasi pariwisata nasional-internasional belum tergeser oleh destinasi lainnya. Indikator penting yang lain adalah pembangunan atraksi buatan yang cukup menonjol. Sejumlah taman hiburan berbasis ekowisata, seperti Bali Park, hadir sebagai atraksi tambahan yang sebelumnya cukup terbatas (Arida \& Damanik, 2012). Fase rejuvenation yang mapan juga terjadi pada destinasi pariwisata Jabar akibat pengembangan infrastruktur pariwisata di Bandung, PuncakCianjur, Bogor, Depok, Bekasi, Pangandaran, Pelabuhan Ratu, Ciamis, Garut, dan lainnya. 
Eksistensi atraksi pariwisata buatan, antara lain: TMII, Taman Safari, Ciater, Trans Studio, membuat kunjungan wisatawan nusantara terus membanjiri kawasan ini. Bandung dan kawasan Puncak-Cianjur, misalnya, selalu penuh (dan macet) oleh kedatangan wisatawan nusantara yang berakhir pekan. Dalam beberapa tahun terakhir, Bandung juga menjadi destinasi menarik bagi wisatawan Malaysia yang dipermudah oleh jalur penerbangan langsung ke dan dari ibukota provinsi itu. Hal ini pulalah yang menyebabkan siklus hidup kedua destinasi provinsi ini tidak masuk ke fase penurunan (decline). Satu hal yang perlu dicatat adalah fakta, bahwa karakteristik pariwisata massal masih mewarnai perkembangan destinasi yang menjalani siklus peremajaan ini. Fakta ini berbeda dengan apa yang diasumsikan oleh Butler dalam model TALC.

\section{SIMPULAN DAN REKOMENDASI}

Studi ini memberikan interpretasi kritis atas data kuantitatif tentang perkembangan pariwisata pada semua provinsi selama 10 tahun. Model TALC yang digunakan dalam studi ternyata mempunyai keterbatasan, terutama untuk memotret siklus hidup destinasi yang berbasis lokus wilayah provinsi. Meskipun demikian dan dengan bertitik-tolak dari analisis di atas, studi ini sampai pada simpulan berikut:

1. Siklus hidup destinasi pariwisata Indonesia berbeda-beda setiap provinsi akibat latar belakang perkembangan, perubahan lingkup wilayah, dan intensitas dan keberlanjutan penyelenggaraan event atraksi pariwisata;

2. Berbeda dengan asumsi dalam model TALC, siklus hidup satu atau beberapa destinasi pariwisata Indonesia tidak selalu positif-vertikal, melainkan juga negatifvertikal yang diakibatkan oleh peristiwa politik dan alam;
3. Berbeda dengan asumsi dalam model TALC, siklus hidup sebagian destinasi pariwisata Indonesia tidak bergeser atau "stasioner" pada fase eksplorasi, meskipun durasi waktu yang dilalui mencapai 10 tahun;

4. Siklus hidup yang bersifat "stasioner" dialami oleh sebagian besar destinasi pariwisata Indonesia pada waktu berada pada salah satu dari enam fase perkembangan;

5. Efek pengembangan infrastruktur dan promosi pariwisata terhadap gerak siklus hidup destinasi berbeda-beda menurut fase perkembangan destinasi tersebut; efeknya pada fase eksplorasi relatif lemah, sedangkan pada fase pengembangan tergolong kuat.

Ada tiga rekomendasi yang perlu disampaikan sebagai implikasi analisis dan kesimpulan di atas. Pertama, para perencana di tingkat provinsi dan pusat sebaiknya menggunakan realitas siklus hidup setiap destinasi sebagai basis perumusan kebijakan pengembangan destinasi, baik di bidang penyediaan dan penguatan infrastruktur maupun peningkatan promosi. Hal ini akan memudahkan tindakan monitoring perkembangan dan pengukuran capaian pada satu periode waktu tertentu. Kedua, studi yang lebih komprehensif tentang siklus hidup destinasi pariwisata perlu dilakukan dengan cara: a) menambah indikator perkembangan, seperti proporsi penduduk lokal yang bekerja di sektor pariwisata, proporsi volume investasi pariwisata, dan jenis atau ragam kelembagaan pariwisata; $b$ ) rentang waktu yang diacu sebagai durasi perkembangan destinasi, misalnya 20, 25 atau 30 tahun. Kelengkapan parameter tersebut akan mampu memotret secara lebih tepat gerak siklus hidup destinasi di masa depan.** 


\section{DAFTAR PUSTAKA}

Andriotis, K. 2010. The Tourism Life Cycle: an Overview of the Cretan Case. (http:// www.google.co.id/\#hl=id\&source=hp\&bi $\mathrm{w}=1360 \&$ bih $=578 \& \mathrm{q}=$ tourism + life + cycle $\&$ $\mathrm{aq}=\mathrm{f} \& \mathrm{aqi}=\mathrm{g} 1 \& \mathrm{aql}=\& \mathrm{oq}=\& \mathrm{fp}=947 \mathrm{~d} 48 \mathrm{c} 16 \mathrm{e}$ 63a19d)

Arida, N. S \& Damanik, J. 2012. Problema Perkembangan Pseudo-Ekowisata di Bali, Jurnal Kepariwisataan Indonesia, 7(1), 5368.

Asia-Pacific Economic Cooperation. 2004. The Impact of SARS on the Singapore Economy and Action taken in Response. Asia-Pacific Economic Cooperation - APBN, 8(12), 672679.

Bo, J \& Zhang, C. 2006. The TALC in China's Tourism Planning: Case Study of Danxia Mountain, Guangdong Province, PRC. In R. G. Butler (ed), The Tourism Area Life Cycle (Vol. 1): Conceptual and Theoretical Issues (pp. 107-116). Clevedon, UK: Channel View Publications.

Booth, A., 1990. The Tourism Boom in Indonesia. Bulletin of Indonesian Economic Studies, 26(3), 45-73.

Boyd, S. W. 2006. The TALC Model and its Application to National Parks: A Canadian Example. In R. G. Butler (ed.), The Tourism Area Life Cycle (Vol. 1): Conceptual and Theoretical Issues (pp. 119-138). Clevedon, UK: Channel View Publications.

Butler, R.W. 1980. The Concept of a Tourist Area Life Cycle of Evolution: Implications for Management of Resources. Canadian Geographer, XXIV(1), 5-12.

Butler, R. 2006a. The Conceptual Context and Evolution of the TALC. In R. G. Butler (ed), The Tourism Area Life Cycle (Vol. 1): Conceptual and Theoretical Issues (pp. 1-6). Clevedon, UK: Channel View Publications.
Butler, R.W. 2006b. The Origins of the Tourism Area Life Cycle. In R. G. Butler (ed), The Tourism Area Life Cycle (Vol. 1): Conceptual and Theoretical Issues (pp. 13-26). Clevedon, UK: Channel View Publications.

Butler, R.W. 2011. Tourism Area Life Cycle. Goodfellow Publishers Limited, Woodeaton, Oxford. http://www. goodfellowpublishers.com

Cohen, E. 1979. The Impact of Tourism on the Hill Tribes of Northearn Thailand. Internationales Asienforum, 10(1/2), 5-38.

Cole, S. 2007. Beyond the Resort Life Cycle: The Micro-Dynamics of Destination Tourism. Journal of Regional Analysis \& Policy, 37(3), 266-278.

Cooper, C. 2002. Sustainability and tourism visions. Paper on VII Congreso Internacional del CLAD sobre la Reforma del Estado y de la Administración Pública, Lisboa, Portugal, 8-11 Oktober. http:// unpan1.un.org/intradoc/groups/ public/ documents/CLAD/clad0044548.pdf

Damanik, J. 2009. Managing the Uncertainty of the Indonesian Tourism Sustainability. Makalah pada International Conference on Sustainable Tourism Management, Maejo University, Chiang Mai, Thailand, 5-8 Mei.

Damanik, J \& Cemporaningsih, Rr. E. 2012. Policy Implications of Tourists' Movement in 'Joglosemar Triangle' of Central Java, Indonesia, International Journal of Multidisciplinary Research, 1(9), 12-17.

Getz, D. 1992. Tourism planning and the destinations life cycle. Annals of Tourism Research, 19(4), 752-770.

Haywood, K. M. 2006. Legitimizing the TALC as a Theory of Development and Change. In R. G. Butler (ed.), The Tourism Area Life Cycle (Vol. 1): Conceptual and Theoretical 
Issues (pp. 29-44). Clevedon, UK: Channel View Publications.

Hitchcock, M \& Putra I. N. D. 2007. Tourism, Development and Terrorism in Bali. Burlington, VT: Ashgate Publishing.

Hoskins, J. 2002. Predatory Voyeurs: Tourists and 'Tribal Violence' in Remote Indonesia. American Ethnologist, 29(4), 797-828.

Johnston, J. D \& Snepenger, D.J. 2006. Residents' Perceptions of Tourism Development Over the Early Stage of TALC. In R. G. Butler (ed.), The Tourism Area Life Cycle (Vol. 1): Conceptual and Theoretical Issues (pp. 222-236). Clevedon, UK: Channel View Publications.

Kamat, S. B. 2010. Destination Life Cycle and Assessment - A Study of Goa Tourism Industry. South Asian Journal of Tourism and Heritage, (3)2, 139-148.

Lombard, D. 2005. Nusa Jawa: Silang Budaya (Batas-Batas Pembaratan). Jakarta: Gramedia Pustaka Utama.

Lumbanraja, V. 2012. Tourism Area Life Cycle in Lake Toba. Indonesian Journal of Geography, 44(2), 150-160.

Marois, J \& Hinch, T. 2006. Seeking Sustainable Tourism in Northern Thailand: The Dynamics of the TALC. In R. G. Butler (ed.), The Tourism Area Life Cycle (Vol. 1): Conceptual and Theoretical Issues (pp. 250-268). Clevedon, UK: Channel View Publications.

Picard, M. 2006. Bali: Pariwisata Budaya dan Budaya Pariwisata. Jakarta: Kepustakaan Populer Gramedia bekerjasama dengan Forum Jakarta-Paris Ecole francaise d'Extreme-Orient.
Plog, S.C. 2001. Why Destination Areas Rise and Fall in Popularity: An Update of a Cornell Quarterly Classic. Cornell Hotel and Restaurant Administration Quarterly, Juni, 13-24.

Pulina, M \& Biagi, B. 2006. Regional public policy and tourism life cycle: the case of Sardinia. Paper presented on 46th Congress of the European Regional Science Association University of Thessaly (Volos, Greece), 30 August - 3 September.

Pusdatin Kemenparekraf, t.t. Perkembangan Wisatawan Nusantara, 2008-2012. http:// www.parekraf.go.id/userfiles / file / winus $\% 202008 \% 20-\% 202012$.pdf

Putra, I.N.D \& Hitchcock, M. 2006. The Bali Bombs and the Tourism Development Cycle. Progress in Development Studies, 6(2), 157-166.

Sofield, T.H.B., 1995. Indonesia's National Tourism Development Plan. Annals of Tourism Research, 23(3), 690-694.

Walpole, M. J \& Goodwin, H. J. 2000. Local Economic Impacts of Dragon Tourism in Indonesia. Annals of Tourism Research, 27(3), 559-576.

World Tourism Organization. 2007. A Practical Guide to Tourism Destination Management. Madrid: World Tourism Organization. 